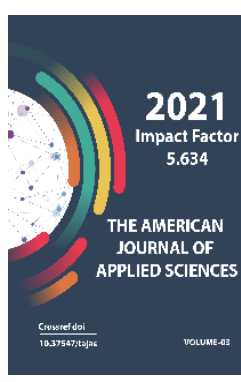

Journal Website: http://usajournalshub.c om/index,php/tajas

Copyright: Original content from this work may be used under the terms of the creative commons attributes 4.0 licence.

\section{Important Aspects Related To Foreign Exchange Operations of Commercial Banks}

\author{
Normet Saparboyevich Ernazarov \\ Head Teacher, Department Of Bank Accounting And Auditing, Tashkent Financial Institute, \\ Tashkent, Uzbekistan \\ Oybek Odilovich Xudoyorov \\ PhD, Head Teacher, Department Of Bank Accounting And Auditing, Tashkent Financial \\ Institute, Tashkent, Uzbekistan
}

\title{
ABSTRACT
}

This article provides analytical, critical and econometric analysis of the factors influencing the offbalance sheet operations of commercial banks of the Republic of Uzbekistan. Factors influencing documentary letters of credit, currency forward transactions, bank guarantee-related transactions, currency spot, currency futures and options from off-balance sheet operations, which are highly profitable for commercial banks, were studied.

\section{KEYWORDS}

Off-balance sheet transaction, forward, futures, options, currency, letter of credit, currency swap, currency spot, deficit, inflation, uncovered letter of credit.

\section{INTRODUCTION}

A number of financial institutions, such as the Central Banks of the developed countries of the world, the International Monetary Fund, the Basel Committee, have conducted research on the development of off-balance sheet operations of commercial banks. These studies are scientifically based on the integrated use of documented forms and types of letters of credit, the expansion of commercial bank guarantee operations, foreign exchange 
options and futures, the role of off-balance sheet operations in risk management of commercial banks. However, in these studies, the issues related to the lack of opportunities for the development of off-balance sheet operations in the context of high levels of financial risk in the activities of commercial banks, low level of diversification of foreign exchange reserves of banks remain relevant.

Several factors simultaneously affect the offbalance sheet operations of commercial banks. However, while the factors that affect each type of off-balance sheet transaction have specific characteristics, some factors can affect all off-balance sheet transactions.

The ultimate goal of radical reforms in the banking system of Uzbekistan is to increase the financial stability of banks, strengthen the competitive environment of commercial banks in the digital economy and, as a result, provide modern banking financial services to customers. Although off-balance sheet operations are an important factor in ensuring the financial stability of banks, there is almost no scientific and theoretical research in this area in the country. In particular, in the practice of commercial banks, there are no foreign exchange options and futures, and more than $90 \%$ of the documented letters of credit opened by banks are covered by secured letters of credit. "Taking measures to improve foreign exchange policy and foreign trade, attract foreign investment into the economy, increase export potential, sustainable development of modern, export-oriented industries, small businesses and private entrepreneurship" [1] is one of the priorities. Ensuring the fulfillment of these tasks remains one of the most pressing issues today.

\section{MATERIALS AND METHODS}

Several factors simultaneously affect the offbalance sheet operations of commercial banks. However, while the factors that affect each type of off-balance sheet transaction have specific characteristics, some factors can affect all off-balance sheet transactions.(shu joyi tepadagi gap bilan bir xil bo'pqopti)

Below we assess the impact of these factors on the off-balance sheet operations of commercial banks.

In our opinion, the main factors influencing the off-balance sheet operations carried with documented letters of credit of commercial banks of the Republic, are:

a) The level of solvency of customers who have the status of a legal entity using the services of a letter of credit of commercial banks.

Due to the high risk level of uncovered letters of credit, commercial banks only issue uncovered letters of credit to customers with a high level of solvency. Therefore, the level of solvency of customers plays an important role in increasing the volume of documented letters of credit opened by commercial banks on the payment obligations of customers.

b) Commercial banks have the opportunity to repay documented letters of credit at the expense of their loans.

In developed countries, if there are no funds available in the payer's current account at the time of receipt by the letter of credit, then the amount of the letter of credit is paid from the term or overdraft loan of the letter of credit [2]. 
In order for a commercial bank to repay documented letters of credit on time from their loans, they must not have an unbalanced liquidity problem. The results of scientific research by a number of Uzbek economists have shown that there is a problem of unbalanced liquidity in commercial banks of the country [3].

One of the main factors influencing the bank guarantee operations of commercial banks is the solvency of customers guaranteed by the bank. This is because if the guaranteed customer is unable to pay due to payment obligations, the bank will be forced to make the payment at its own expense.

Also, the ability of the bank-guaranteed customer to fulfill its obligations in a timely manner is one of the main factors influencing the bank guarantee operations of commercial banks.

One of the main reasons for the mass bankruptcy of U.S. banks during the Great Recession was that commercial banks provided large amounts of guarantees on customers' payment obligations and payments were made by banks as a result of their insolvency [4].

In our opinion, one of the main factors influencing the development of forward operations of commercial banks of the Republic of Uzbekistan is the large difference between the interest rate on loans in the transaction currency and the interest rate on deposits in the appraisal currency.

It is known that in our Republic our national currency is the soum, and for us all foreign currencies are transaction currencies.
Banks in Uzbekistan currently use market interest rates, mainly London Inter-Bank Offered Rate (LIBOR) as the interest rate of the transaction currency. The IZIBID rate is used as the market rate for UZS deposits.

There are no currency options and futures in the banking practice of the Republic of Uzbekistan. Therefore, it is not possible to perform an analysis of the factors affecting them.

The main part of off-balance sheet operations of commercial banks of the Republic in foreign currencies is currency swap operations.

In our opinion, the factors influencing the currency swap operations of commercial banks of the Republic are:

1. The degree of volatility of the spot rate of the national currency.

Since currency swap transactions are a combination of spot and forward transactions, the volatility of the national currency spot rate is one of the main factors influencing currency swap transactions.

In turn, the high level of volatility of the national currency spot rate is explained by the following factors:

- High inflation rate (in 2020, the annual inflation rate in the country was $11.1 \%$ [5]);

- High growth rate of money supply;

- Execution of the state budget with a deficit;

- The country's foreign trade balance has a large negative balance (in 2020, the country's foreign trade balance had a negative balance of 6 billion US dollars [6]). 


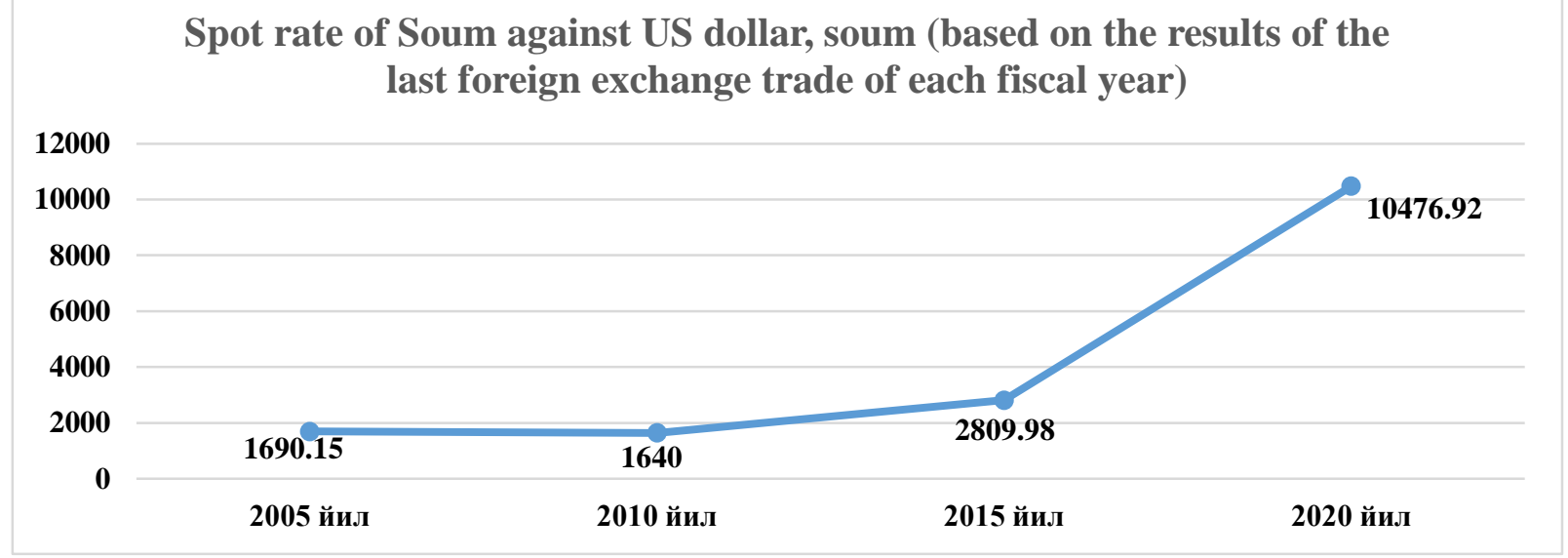

1-figure. Spot rate of Soum against US dollar, soum (based on the results of the last foreign exchange trade of each fiscal year) [7]

Figure 1 shows that in 2010-2020, the volatility of the spot exchange rate against the US dollar was high. This has a negative impact on the development of currency swap transactions.

2. The fact that the Republic of Uzbekistan has a large deficit of foreign trade balance;

Having a large deficit of the balance of foreign trade creates a strong pressure on the spot rate of the national currency.

3. High inflation rate;

In 2020, the inflation rate in the country was $11.1 \%[8]$.

It should be noted that the existence of a direct and strong link between inflation and the state budget is scientifically substantiated. In particular, the reduction of the state budget deficit to 1 percentage point of GDP has been shown to lead to a decrease in inflation to 8.75 percentage points [9].It is also based on the existence of a strong correlation between inflation and fiscal policy parameters in shortterm cycles [10].
The practical significance of currency swap operations for commercial banks is reflected in the following:

While the sale of foreign currency under a swap operation allows you to reduce the long currency position in that currency, the purchase of foreign currency allows you to reduce the short currency position in that foreign currency.

Placement of foreign currency funds in "Nostro" correspondent accounts in foreign currencies of commercial banks, for example, placement of funds in "Nostro" correspondent accounts in US dollars by swap is carried out in the following order:

- Funds available in the bank's dollar account "Nostro" are sold at the spot rate in one of the leading currencies, for example, the Swiss franc;

- Proceeds received in francs are placed as a deposit in one of the Swiss banks for a certain period, for example, for a period of 3 months; 
- Enters into a 3-month forward contract to purchase the same amount of dollars as the commercial bank sold on the spot;

- At the end of the 3-month period, the commercial bank repays the deposit in Swiss francs with interest accrued on it and buys US dollars for this amount under a forward contract.

4. Swap operations allow diversification of foreign exchange reserves of a commercial bank and its customers.

The results of research by a number of Uzbek economists show that the level of diversification of foreign exchange reserves of commercial banks in the country is very low, they make up the bulk of foreign exchange reserves (more than 90\%) in US dollars [11].

Documentary letters of credit opened by JSC "Aloqabank" and the factors influencing them [12].

\begin{tabular}{|c|c|c|c|c|c|c|c|c|c|c|c|}
\hline № & Кўрсаткичлар & 2010 & 2011 & 2012 & 2013 & 2014 & 2015 & 2016 & 2017 & 2018 & $\begin{array}{c}201 \\
9\end{array}$ \\
\hline 1. & $\begin{array}{l}\text { The amount of letters of } \\
\text { credit opened by the } \\
\text { bank (in bln. soums) }\end{array}$ & 7,6 & 9,1 & 15,5 & 9,6 & 21,5 & 6,6 & 12,3 & 39,4 & 73,8 & $\begin{array}{c}87 \\
1\end{array}$ \\
\hline 2. & $\begin{array}{l}\text { The amount of tokens } \\
\text { until the bank receives } \\
\text { the request (in bln. } \\
\text { soums) }\end{array}$ & $\begin{array}{c}118 \\
0\end{array}$ & $\begin{array}{c}134 \\
0\end{array}$ & $\begin{array}{c}177 \\
0\end{array}$ & $\begin{array}{c}223 \\
0\end{array}$ & $\begin{array}{c}271 \\
0\end{array}$ & $\begin{array}{c}339 \\
0\end{array}$ & $\begin{array}{c}405 \\
0\end{array}$ & $\begin{array}{c}1314 \\
0\end{array}$ & $\begin{array}{c}1036 \\
, 0\end{array}$ & $\begin{array}{c}106 \\
7\end{array}$ \\
\hline 3. & Inflation rate,(\%) & 7,3 & 7,6 & 7,0 & 6,8 & 6,1 & 5,6 & 5,7 & 14,4 & 14,3 & 15,2 \\
\hline 4. & $\begin{array}{c}\text { Depreciation rate of the } \\
\text { national currency against } \\
\text { the US dollar, (\%) }\end{array}$ & 8,5 & 9,5 & 10,5 & 11,0 & 10,0 & 16,0 & 15,0 & 92,4 & 2,7 & $\begin{array}{c}14 \\
0\end{array}$ \\
\hline 5. & $\begin{array}{c}\text { Average annual interest } \\
\text { rate on loans in national } \\
\text { currency, }(\%)\end{array}$ & 13,4 & 12,5 & 13,5 & 13,0 & 12,5 & 11,4 & 11,5 & 18,5 & 20,5 & $\begin{array}{c}24 \\
2\end{array}$ \\
\hline 7. & Import, (in bln. dollars) & 8,8 & 10,5 & 12,0 & 13,8 & 13,9 & 12,4 & 12,1 & 14,0 & 19,4 & $\begin{array}{c}24, \\
3\end{array}$ \\
\hline
\end{tabular}

Implementation of currency swap operations will reduce the share of the US dollar in the foreign exchange reserves of commercial banks and increase the share of other currencies, which will increase the degree of diversification of foreign exchange reserves of banks. In turn, increasing the level of diversification of foreign exchange reserves plays an important role in reducing the level of currency risk.

\section{RESULTS}

We conducted an econometric analysis in order to examine the extent to which the volume of off-balance sheet transactions of commercial banks is impacted by factors. 
This econometric analysis was performed on a multi-factor regression and correlation method based on data from 2010-2019. As a result factor, the amount of letters of credit opened by JSC "Aloqabank" was taken, and the causal factors were the deposits of commercial banks in the country, the annual inflation rate, the annual devaluation of the soum against the US dollar, the average interest rate on loans in national currency and imports.

The following was observed in the correlation analysis performed to study the dependencies.

In this case, the resulting character $-\mathrm{Y}$;
Amount of letter of credit of JSC "Aloqabank", (in bln. soums) - AS;

\section{Characters of factors}

X1 - DS- Amount of deposits, in bln. soums;

X2 - IF- Annual rate of inflation, \%;

$\mathrm{X}_{3}$ - DV - Annual devaluation rate of the soum against the US dollar, \%;

X4- KF- Average annual interest rate on loans in national currency, \%;

X5- IM - Volume of import, in bln. Soums

\section{Correlation table}

\begin{tabular}{|c|c|c|c|c|c|c|}
\hline & $\mathbf{Y}$ & $\mathbf{X 1}$ & $\mathbf{X 2}$ & $\mathbf{x 3}$ & $\mathbf{x 4}$ & $\mathbf{x 5}$ \\
\hline $\mathbf{y}$ & 1,000 & 0,823 & 0,903 & 0,091 & 0,966 & 0,938 \\
\hline $\mathbf{X 1}$ & 0,823 & 1,000 & 0,920 & 0,602 & 0,847 & 0,718 \\
\hline $\mathbf{X 2}$ & 0,903 & 0,920 & 1,000 & 0,425 & 0,960 & 0,762 \\
\hline $\mathbf{x 3}$ & 0,091 & 0,602 & 0,425 & 1,000 & 0,231 & $-0,019$ \\
\hline $\mathbf{x 4}$ & 0,966 & 0,847 & 0,960 & 0,231 & 1,000 & 0,880 \\
\hline $\mathbf{x} 5$ & 0,938 & 0,718 & 0,762 & $-0,019$ & 0,880 & 1,000 \\
\hline
\end{tabular}

As can be seen from the table above, almost all factors affect the change in the size of the letter of credit (except for the change in the exchange rate of the soum against the US dollar). In particular, the correlation between the average interest rate of the loan and the volume of the letter of credit is very high, i.e. the correlation coefficient is 0.966 .

In the econometric analysis of these factors, a correlation matrix test of the variables was performed to form a selective multifactor econometric model with a high effect of the selected outcome variables so that the effect of the free variable on the inverse variable does not lead to loss. The mathematical function view of this model is represented as follows.

$A S=F(D S, I F, D V, K F, I M)$ (1- formula)

In this case: AS-AT - the amount of the letter of credit of "Aloqabank", bln. sum; DS - the amount of deposits in billions of soums; IFannual inflation rate, in percent; DV - annual devaluation rate of soum against US dollar, in percent; KF - average annual interest rate on 
The American Journal of Applied sciences

(ISSN - 2689-0992)

Published: April 30, 2021 | Pages: 157-165

loans in national currency, in percent; IM import volume, bln.doll

Based on the above mathematical formula, we have formulated our econometric model in our study. In the development of a multifactor regression model, the amount of the letter of credit of a commercial bank and the factors influencing it were taken as follows:
A multifactor regression model was constructed with DS - the amount of deposits; IF - annual inflation rate; DV- annual devaluation rate of soum against US dollar; KF - average annual interest rate on loans in national currency; IM-import volume (Table 3).

Results of the multivariate regression and correlation analysis based on the Eviews program [13].

\section{Dependent variable : In AS}

\section{Method: The smallest}

squares

\begin{tabular}{|l|l|l|l|l|}
\hline \multicolumn{1}{|c|}{ Variable } & Coefficient & Default error & t-statistics & $\begin{array}{l}\text { Probability (P- } \\
\text { value) }\end{array}$ \\
\hline Ln DS (x1) & 0,030 & 0,017 & 1,786 & 0,149 \\
\hline Ln IF (x2) & 0,340 & 3,233 & 0,105 & 0,921 \\
\hline Ln DV (x3) & $-0,345$ & 0,131 & $-2,623$ & 0,059 \\
\hline Ln KF (x4) & 3,076 & 2,909 & 1,058 & 0,350 \\
\hline Ln IM (x5) & 1,066 & 1,375 & 0,775 & 0,482 \\
\hline C & $-44,914$ & 11,806 & $-3,804$ & 0,019 \\
\hline Determination coefficient & 0,988643 & $\begin{array}{l}\text { The corrected coefficient of } \\
\text { determination }\end{array}$ & 0,974446 \\
\hline & 0,974446 & Standard regression error & 4,686292 \\
\hline $\begin{array}{l}\text { The value of the maximum } \\
\text { similarity function }\end{array}$ & $-25,05435$ & F-statistics & \\
\hline
\end{tabular}

Based on the above calculations, the following multifactor regression model was formed.

InAS $=-44.914+0.030 \mathrm{lnDS}+0.340 \mathrm{lnIF}-$ $0.345 \ln D V+3.076 \ln K F+1.066 \ln \mid \mathrm{M}+\varepsilon$

The corrected coefficient of correction in the formed model shows that $97 \%$ of letters of credit of commercial bank (AS) are depends on the factors formed in the model: DS- the amount of demand deposits of bank, IF-annual inflation rate, DV-soum annual devaluation rate against US dollar, KF-loans in national currency, $I M$ - imports. The remaining 3 percent is due to other factors, which are not taken into account.

Discussion: A number of economists have expressed their views on the off-balance sheet operations of commercial banks. А.Малых has formed his conclusions on letters of credit, which are one of the most widely used forms of accounting in off-balance sheet banking operations. According to him, "A documented 
letter of credit has the following advantages for the buyer:

- Documented letter of credit allows the buyer to receive the payment in full after the shipment of the goods;

- A documented letter of credit guarantees the buyer the necessary transport and commercial documents;

- The documented letter of credit allows the buyer to receive additional financing from the issuing bank "[14].

Another economist, J. Zinki, concluded that if a commercial bank, for some reason, "fails to hedge, it can use off-balance sheet methods for hedging, such as futures, forwards, options, and swaps" [15].

\section{CONCLUSION}

The factors influencing the off-balance sheet operations of commercial banks of the Republic of Uzbekistan are as follows:

- The level of solvency of customers with the status of a legal entity using the letter of credit services of commercial banks;

- Possibility of commercial banks to repay documented letters of credit at the expense of their loans;

- Solvency of bank-guaranteed customers;

- Timely fulfillment of obligations by client, which are guaranteed by the bank;

- The negative impact of the global financial and economic crisis on the guarantee operations of commercial banks;

- Large difference between the interest rate on loans in the transaction currency and the interest rate on deposits in the appraisal currency;
- High level of volatility of the spot rate of the national currency.

Summing up our econometric model, it should be noted that, taking other factors into account, a $1 \%$ increase in deposits would increase the volume of letters of credit of JSC "Aloqabank" by $0.03 \%$, an increase in inflation by $1 \%$, the volume of letters of credit of commercial banks by $0.34 \%$ and an increase in the annual interest rate of loans in national currency by $1 \%$ will lead to an increase in the amount of the commercial bank's letter of credit by $3.08 \%$. However, an increase in the annual devaluation of the soum against the US dollar by $1 \%$ leads to a decrease in the amount of letters of credit of commercial banks by $0.34 \%$ In general, excluding other factors, the simultaneous growth of DS - the amount of deposits, IF - the annual rate of inflation, DV the annual devaluation of the soum against the US dollar, KF - the average annual interest rate on loans in national currency, IM - imports by $1 \%$ leads to an increase in the amount of the letter of credit of a commercial bank by $4.167 \%$.

\section{REFERENCES}

1. Ўзбекистон Республикаси Президентининг 2017 йил 2 сентябрдаги “Валюта сиёсатини либераллаштириш бўйича биринчи навбатдаги чоратадбирлар тўғрисида"ги ПФ-5177-сон Фармони.(lex.uz/docs/3326421)

2. О.И. Лаврушина Банковское дело. Учебник. под ред. - М.: КНОРУС, 2016. $800 \mathrm{c}$.

3. З.А.Холмахмадов Тижорат банклари фаолиятининг барқарорлигини илғор хориж тажрибаси асосида таъминлаш имкониятлари//«Халқаро молия ва 
хисоб» илмий электрон журнали. Тошкент, 2017. - №4. - Б.

4. Ф.С. Мишкин Экономическая теория денег, банковского дела и финансовых рынков. 7- изд. Пер.англ. - М.: ООО «И.Д. Вильямс», 2013. - 880 с.

5. www.cbu.uz - сайти (Ўзбекистон Республикасининг Марказий банки) маълумотлари

6. www.stat.uz сайти (Ўзбекистон Республикаси Давлат статистика қўмитаси) маълумотлари.

7. www.cbu.uz (Валюталарнинг курслари) сайти (Ўзбекистон Республикаси Марказий банки) сайти маълумотлари.

8. www.cbu.uz- Ўзбекистон Республикаси Марказий банки расмий веб сайти маълумотлари.

9. Catao L., Terrones M. Fiscal Deficits and Inflation // Working Paper. 65. IMF. - P.63 $-67$.

10. Calderon C., Schmidt-Hebbel K. What Drives Inflation in the World//Central bank of Chile Working Papers, 2008. - № 491. P. 1-20.

11. Бобакулов Т.И. Ўзбекистон Республикасида миллий валюта курсининг барқарорлигини таъминлаш борасидаги муаммолар ва уларни хал қилиш йўллари. и.ф.д. илм. дар. ол. уч. тақд. эт. дисс. автореф. - Тошкент: БМА, 2008. - 33 б.;

12. АТ “Алоқабанк”нинг жамланма баланс маълумотлари ва Ўзбекистон Республикаси Марказий банкининг статистик маълумотлари асосида тузилган.

13. Eviews дастури ёрдамида муаллиф томонидан тайёрланган.

14. Малых А. В. Документарный аккредтив в международные торговли//Финансы и кредит. - Москва, 2007. -№47. - С. 20-31.
15. Синки Дж. Финансовый менеджмент в коммерческом банке и в индустрии финансовых услуг. Пер. с англ. - М.: Альпина Паблишер, 2017. - С. 807. 